\title{
Gender Differences in Financial Decisions
}

\author{
Jeetendra Dangol'
}

\begin{abstract}
This paper examines the gender differences in financial decision-making of university students who are young, single, childless individuals that have at least average financial literacy and very small or no income. This paper is based on the survey questionnaires developed by Grable and Lytton (2003), distributed and collected from 100 students (50 men and 50 women) by using convenience sampling technique. The study finds that men and women differ in their financial decision. Women are less risk taker than men in financial decision-making; it indicates that women prefer to safer investment.
\end{abstract}

Key Words: Financial decision, financial risk tolerance, gender

\section{INTRODUCTION}

Financial decisions represent important part of individual's life. According to Cramer, Hartog, Jonker, and Van Praag (2001), individuals who are more risk tolerant can earn more money. They also pointed out that people who are more risk tolerant such as entrepreneurs are more productive and can contribute more to the national income. It indicates that a country needs more risk tolerant people to attain higher economic growth. Shaw (1996) highlighted that individuals with risk taking behaviour tend to work more in risky environments. Thus, the risk is one of the important factors of financial decisions.

Both women and men make financial decisions such as forming investment portfolio and choosing pension plan. Their financial decisions have great impact on their prosperity. However, many aspects of their behaviours in this regard, differ between women and men (Brokesova, 2013). According to Flynn, Slovic and Mertz (1994), Jianakoplos and Bernasek (1998), and Masters (1989) women are more risk averse than men and they engage in less risky activities. This risk adverse behaviour influences on their financial decisions and decreases returns to women investors. It indicates that the financial decision making is influenced by the gender within the similar kinds of financial and investment opportunities to men and women.

1. Dr. Dangol is Associate Professor at Tribhuvan University, Faculty of Management (FOM). He is also a member of Finance Subject Committee at FOM, TU. He can be reached at jdangol@gmail.com 
The main objective of the paper is to examine the role of gender in financial decisionmaking in the sample of the university students. They represent young, single, childless individuals that have at least average financial literacy, and very small or no income Brokesova (2013). From the perspective of life cycle theory, this sample also represents individuals that start their financial decision-making near future.

The subsequent sections of the paper are in the following order. Section II presents a brief review of previous studies regarding the role of the gender in financial decision. This part also includes development of hypothesis. Similarly, Section III outlines the methodology employed in this study. Section IV presents the results and discussion, and finally, Section $V$ contains conclusions of the paper.

\section{LITERATURE REVIEW AND HYPOTHESIS DEVELOPMENT}

Bruce and Johnson (1994), and Al-Ajmi (2008) found that women take less investment risk as compared to men. Schubert (2006) described that men are less risk averse than women. Similarly, Jianakoplos and Barnesek (1998) reported that a far lower percentage of women than men are willing to take any financial risk at all. These studies indicate that male investors take higher risk than the female investors do.

The important part of the financial-decision is determined by the level of personal financial risk tolerance. According to Grable (2000), personal financial risk tolerance represents the maximum amount of uncertainty that individual is willing to accept when making the financial decision. Burton (2001) argued that investment decision should be realistic about market return in exchange for the risk is taken by investors. Risk on financial decision is guided by the different factors, such as, gender, education, age, income and type of work. But gender has privileged position (Brokesova, 2013). Venter, Michayluk and Davey (2012) argued that gender represents a stabile factor that does not traditionally change during the individual's life in contrary to age, income, education or mental condition.

Women are less risk tolerant in their financial decisions. However, the differences are not ultimate (Brokesova, 2013). Stronger effect of gender is discovered in gamble choices (Eckel \& Grossman, 2002), sure loss (Powell \& Ansic, 1997), and composition of risky assets in portfolios (Jianakoplos \& Barnesek, 1998). According to Barber and Odean (2001), women were found less confident in the areas related to finance. It means women have lower risk tolerance in areas connected to the financial and investment knowledge and experiences. On the other hand, individuals have to be aware of his/her level of financial risk tolerance to make suitable financial decision. However, Grable and Roszkowski (2007) found that women underestimate their financial risk tolerance in comparison to psychometrically measured levels. On the contrary, men over-estimated their tolerance for financial risk. Therefore, the following are the hypothesis statements:

$\mathrm{H}_{1}$ : Women are less financial risk tolerant.

$\mathrm{H}_{2}$ : Gender differences in financial decisions are higher in the area of gambles, sure losses and investment strategies. 
$\mathrm{H}_{3}$ : Women have lower risk tolerance in areas connected to the financial and investment knowledge and experiences.

$\mathrm{H}_{4}$ : Women significantly underestimate their financial risk tolerance in comparison to men.

\section{METHODOLOGY}

The study is based on primary data collected from a sample of students based on convenience sampling technique. The questionnaire was administered to a sample of 100 students studying business/ finance at master's level (MBA, MFC, MBA GLM) at the School of Management, Tribhuvan University in December 2017. The sample consist 50 male and 50 female students. The survey instrument added a few questions related to demographic aspects of the respondentson a questionnaire developed by Grable and Lytton (2003).

Grable and Lytton (2003) developed 13 questions to measure the financial risk tolerance, where a higher mean score indicates the high risk taker and a lower mean score indicates less risk taker respondents. The maximum score that a respondent can get is 44 indicating a very high financial risk tolerance. A score of 12 , on the other hand, indicates the opposite extreme, that is, having a very low risk tolerance.

The questionnaire was distributed to the students after giving a short orientation about the topic of financial risk, and then they were asked to evaluate themselves. The filled-up questionnaires were collected immediately. The respondents represent young, single, childless individuals that have at least average financial literacy and very small or no income. They too had minimal experience on financial and investment decisionmaking. All of these characteristics predetermine higher level of financial risk tolerance level and by controlling all of these characteristics, able to identify gender effect in financial decisions.

Table 1 shows the seven specific dimensions of financial risk tolerance of 13 questions developed by Grable and Lytton (2003).

Table 1: Dimensions of Financial Risk Tolerance

\begin{tabular}{cll}
\hline Dimension number & \multicolumn{1}{c}{ Dimensions } & \multicolumn{1}{c}{ Items in the Questionnaire } \\
\hline DIM 1 & Guaranteed vs. probable gambles & Questions 2, 8 and 13 \\
DIM 2 & Choice between sure loss and sure gain & Question 8 \\
DIM3 & Risk as experience and knowledge & Questions 1, 4, 6, 7 and 11 \\
DIM4 & Risk as a level of comfort & Questions 1, 3, 6, 7 and 12 \\
DIM5 & Speculative risk & Questions 2, 8 and 13 \\
DIM6 & Prospect theory & Questions 9, 10 and 12 \\
DIM7 & Investment risk & Questions 4, 6 and 11 \\
\hline
\end{tabular}

Kolmogorov-Smirnov tests were conducted to confirm normality of the distribution. To confirm normal distribution p-value (Sig.) for the Kolmogorov-Smirnov test has to be greater than 0.05 . As per expectation Kolmogorov-Smirnov $Z$ value is 0.936 ( $p$ value $=$ 
$0.345)$ showing data distribution of financial risk tolerance is normal. Thus, the paper used t-test, nonparametric Mann-Whitney $U$ and Wilcoxon Signed Ranks tests for analysis of differences between gender groups in individual dimensions as well as for the analysis of financial risk tolerance estimations.

\section{RESULTS AND DISCUSSIONS}

The average age of the respondents is 23.38 years. Average level of financial risk tolerance of men is 33.73 points (standard deviation 5.09) which is higher than women 29.38 points (standard deviation 4.58). The mean difference between points obtained by genders is 4.40 ( $p$-value $=0.000$ ) indicating statistically significant difference in average level of financial risk tolerance between men and women (Table 2). Therefore, the result supports the first hypothesis $\mathrm{H}_{1}$ : Women are less financial risk tolerant. Hence, it supports that the Nepalese female investors are less likely to hold risky assets in their portfolio. This may happen due to their risk preferences. One more reason may be the dominant role of male members of the family in most financial decisions. The result is consistent with Brokesova (2013), Sharma, Chalise and Dangol (2017), Bruce and Johnson (1994), Schubert (2006), Jianakoplos and Barnesek (1998), Al-Ajmi (2008) and Rahmawati et al. (2015), who found that women take less investment risk as compared to men.

Table 2 Overall descriptive statistics and mean difference t-test

\begin{tabular}{ccccc}
\hline Gender & N & Mean & Std. Deviation & Mean Difference \\
\hline Male & 50 & 33.78 & 5.09 & $4.40^{*}$ \\
Female & 50 & 29.38 & 4.58 & $(.000)$ \\
\hline
\end{tabular}

Note: Figures in parenthesis is p-value

* Statistically significant at $5 \%$ level

The mean values for women are lesser for all dimensions of risk being analysed. The majority of these differences between genders are statistically significant at $5 \%$ level of significance except dimension 6 (Prospect Theory). The mean values as well as results of Mann-Whitney $\mathrm{U}$ test are presented in Table 3.

The $84 \%$ of the men choose the option of "a real gambler or willing to take risks after completing adequate research" whereas only $62 \%$ women choose this option. It indicates that men are higher risk takers than women. In dimension 3 (risk as experience and knowledge) the focus is on the level of experiences and financial literacy. As mentioned before, students have at least average level of financial literacy. However, their experiences with investment and financial services are minimal. Thus, the paper finds significant difference on dimension 3 (risk as experience and knowledge) between men and women. The result is consistent with Brokesova (2013). Goldberg (1995) and, Grable and Joo (1997) also argued that the higher levels of financial knowledge and experiences are in relation with higher level of financial risk tolerance. 
Table 3 Descriptive statistics and Mann-Whitney U test

\begin{tabular}{llccccccc}
\hline & & DIM1 & DIM2 & DIM3 & DIM4 & DIM5 & DIM6 & DIM7 \\
\hline Men & Minimum & 6 & 2 & 7 & 19 & 6 & 3 & 4 \\
& Maximum & 12 & 4 & 17 & 27 & 12 & 9 & 10 \\
& Mean & 9.68 & 3.32 & 14.00 & 23.68 & 9.68 & 6.94 & 8.00 \\
\multirow{4}{*}{ Women } & Std. dev. & 2.05 & .79 & 2.03 & 2.09 & 2.05 & 1.49 & 1.20 \\
& Minimum & 3 & 1 & 7 & 16 & 3 & 3 & 4 \\
& Maximum & 11 & 4 & 17 & 27 & 11 & 9 & 10 \\
& Mean & 7.92 & 2.82 & 12.38 & 21.94 & 7.92 & 6.38 & 7.08 \\
\multirow{4}{*}{ Mann-Whitney U } & 1.71 & .80 & 1.92 & 2.04 & 1.71 & 1.68 & 1.40 \\
\multirow{2}{*}{$Z$} & Std. dev. & 679 & 835 & 677 & 718 & 679 & 989 & 756 \\
& & $-3.986^{*}$ & $-3.045^{*}$ & $-4.001^{*}$ & $-3.710^{*}$ & $-3.986^{*}$ & -1.840 & $-3.504^{*}$ \\
& $(.000)$ & $(.002)$ & $(.000)$ & $(.000)$ & $(.000)$ & $(.066)$ & $(.000)$ \\
\hline
\end{tabular}

Note: Figures in parenthesis are $p$-value

* Statistically significant at $5 \%$ level

There is statistically significant difference between decisions of men and women in the Dimensions 2 (choice between sure lose and sure gain), Dimension 4 (risk as a level of comfort), Dimension 5 (speculative risk) and Dimension 7 (investment risk) at $5 \%$ level of significance. It indicates that men reveal higher risk loving attitude towards investment decision-making. The behaviour of men and women are similar regarding Prospect Theory (Dimension 6). It shows that they uncover average risk tolerance. Therefore, the result support hypothesis $2, \mathrm{H}_{2}$ : Gender differences in financial decisions are higher in the area of gambles, sure losses and investment strategies. The study finds statistically significant relation between gender and behaviour in the area of gambles and sure losses. This result contradicts with the findings of Brokesova (2013). Similarly, the study result supports hypothesis $3, \mathrm{H}_{3}$ : Women are lower risk tolerance in areas connected to the financial and investment knowledge and experiences. It indicates that the significant relationship between gender and investment behaviour. The finding is consistent with the study of Brokesova (2013).

Table 4: Wilcoxon Signed Rank test

\begin{tabular}{clcccc}
\hline Gender & Level of financial risk tolerance & N & Mean & $\begin{array}{c}\text { Standard } \\
\text { deviation }\end{array}$ & $\mathbf{Z}$ \\
\hline \multirow{2}{*}{ Male } & Self-estimated & 50 & 2.77 & 0.414 & ${ }^{*}-3.824 a$ \\
& Identified by questionnaire & 50 & 3.16 & 0.792 & $(.000)$ \\
\multirow{2}{*}{ Women } & Self-estimated & 50 & 2.43 & 0.387 & ${ }^{*}-1.988 a$ \\
& Identified by questionnaire & 50 & 2.66 & 0.798 & $(.047)$ \\
\hline
\end{tabular}

Note: a. Based on positive ranks

Figure in parenthesis are $p$-value

* Statistically significant at $5 \%$ level

According to Brokesova (2013), ability to estimate true level of their own financial risk tolerance represents an important competence for every individual. However, persons usually fail in this assignment. The paper finds that women as well as men underestimate 
their financial risk tolerance (Table 4). These differences are higher in men group with statistical significance. Women underestimate their level of financial risk tolerance. So, the result support hypothesis $4, \mathrm{H}_{4}$ : Women significantly underestimate their financial risk tolerance in comparison to men. The results show the gender differences between selfestimated level and level identified by the questionnaire regarding the level of financial risk tolerance. The finding contradicts with the results of Brokesova (2013), who found insignificant differences between self-estimated level and level identified by questionnaire in both men and women.

\section{CONCLUSIONS}

The objective of this paper was to examine the role of gender in financial decisionmaking in the group of the university students. The sample represents masters' level students who are young, single, childless individual that have at least average financial literacy and very small or no income.

The data analysis supports all four hypotheses. Women prefer safer options in financial decisions. These differences were evident in all dimensions of risk. However, in the area of Prospect Theory, gender influence was not statistically significant. Consequently, gender played an important role in cases where experience and knowledge were very important among Nepali students. Women and men also underestimated their financial risk tolerance, where the trend is more prevalent among men. Overall, men and women differed in their financial decisions. Women are less risk taker than men during financial decision-making; it indicates that women prefer to safer investment.

\section{REFERENCES}

Al-Ajmi, J. Y. (2008). Risk tolerance of individual investors in an emerging market, International Research Journal of Finance and Economics, 17, 15-26.

Barber, B. \& Odean, T. (2001). Boys will be boys: Gender, overconfidence, and common stock investment. Quarterly Journal of Economics, 116, 261-292.

Brokesova, Z. (2013). Gender differences in financial decisions. 1st Global Virtual Conference, April 8-12.2013, 119-122

Bruce, A., \& Johnson, J. (1994). Male and female betting behavior: New perspectives. Journal of Gambling Studies, 10, 183-198.

Burton, J. (2001). Investment Titans: Investment insights from the minds that move wall mart. New York: McGraw Hill Companies.

Cramer, J., Hartog, J., Jonker, N., \&. Van Praag,C. M. (2001). Low risk aversion encourages the choice for entrepreneurs: An Empirical test of truism. Journal of Economic Behavior and Organization, 48(1), 29-36.

Eckel, C. \& Grossman, P. (2002). Sex differences and statistical stereotyping in attitudes towards financial risk. Evolution and Human Behaviour, 23, 281-295

Flynn, J., Slovic, P. \& Mertz, C. (1994). Gender, race, and perception of environmental health risk. Risk Analysis, 14, 1101-1108.

Goldberg, S. (August, 1995). Yes, but how do you feel about this investment? Kiplinger's Personal Finance Magazine, 68-71

Grable, J. (2000). Financial risk toleranceand additional factors that affect risk taking in everyday money matters. Journal of Business and Psychology, 14, 625-630. 
Grable, J., \& Joo, S. (1997). Determinants of risk preference: Implications for family and consumer science professionals. Family Economics and Resource Management Biennial, 2, 19-24.

Grable, J., \& Lytton, R. (2003). The development of a risk assessment instrument: A follow-up study. Financial Service Review, 12, 257-274.

Grable, J., \& Roszkowski, M. (2007). Self-assessments of risk tolerance by women and men. Psychological Reports, 100, 795-802.

Jianakoplos, N., \& Bernasek, A. (1998). Are women more risk averse? Economic Inquiry, 36, 620-630.

Masters, R. (1989). Study examines investors' risk taking propensities. Journal of Financial Planning, 36, 151-155.

Powell, M., \& Ansic, D. (1997). Gender differences in risk behaviour in financial decision-making: An experimental analysis. Journal of Economic Psychology, 18, 605-628.

Rahmawati, K. M. D., Kambuaya, M., Jamil, F., \& Muneer, S. (2015). Determinants of the risk tolerance of individual investors. International Journal of Economics and Financial Issues, 5, 373-378.

Schubert, R. (2006). Analyzing and managing risk - On the importance of gender differences in risk attitudes. Managerial Finance, 9, 706-715.

Sharma, D. R., Chalise, M. \& Dangol, J. (2017). Risk tolerance behaviour of individual Nepalese investors. Sona Global Management Review, 11(2), 63-70.

Shaw, K. L. (1996). An empirical analysis of risk aversion and income growth. Journal of Labor Economics, 14(4), 626-653.

Venter, G. Van de., Michayluk, D., \& Davey, G. (2012). A longitudinal study of financial risk tolerance. Journal of Economic Psychology, 33, 795-796. 